OPEN ACCESS

Edited by:

Andrea Serra

University of Pisa, Italy

Reviewed by:

Barry J. Bradford,

Michigan State University,

United States

Manuel Gonzalez Ronquillo, Universidad Autónoma del Estado de

México, Mexico

${ }^{*}$ Correspondence:

Cletos Mapiye

cmapiye@sun.ac.za

Specialty section:

This article was submitted to Animal Nutrition and Metabolism,

a section of the journa

Frontiers in Veterinary Science

Received: 15 June 2020

Accepted: 26 August 2020 Published: 25 September 2020

Citation:

Semwogerere F, Katiyatiya CLF

Chikwanha OC, Marufu MC and Mapiye C (2020) Bioavailability and Bioefficacy of Hemp By-Products in

Ruminant Meat Production and Preservation: A Review.

Front. Vet. Sci. 7:572906.

doi: 10.3389/fvets.2020.572906

\section{Bioavailability and Bioefficacy of Hemp By-Products in Ruminant Meat Production and Preservation: A Review}

\author{
Farouk Semwogerere ${ }^{1}$, Chenaimoyo L. F. Katiyatiya ${ }^{1}$, Obert C. Chikwanha ${ }^{1}$, \\ Munyaradzi C. Marufu ${ }^{2}$ and Cletos Mapiye ${ }^{1 *}$ \\ ${ }^{1}$ Department of Animal Sciences, Faculty of AgriSciences, Stellenbosch University, Stellenbosch, South Africa, ${ }^{2}$ Department \\ of Veterinary Tropical Diseases, Faculty of Veterinary Science, University of Pretoria, Pretoria, South Africa
}

Plant by-products obtained from agro-industrial processes require valorisation to demonstrate their potential for enhancing animal health, meat production, and shelf life extension. One example is the fast-growing hemp industry, which produces seeds, leaves, seed oil, and cake. Studies on the nutritional value of hempseed cake have shown it can be a valuable source of protein in ruminant diets. However, there is limited documentation on the bioavailability and bioefficacy of hemp phytochemicals for improving ruminant health, production, and extending meat shelf life. The current review provides an overview of existing information on nutrient and phytochemical composition of hemp by-products, their bioavailability, and bioefficacy, and explores current limitations and prospects regarding their valorisation.

Keywords: bioactive profile, digestibility, hempseed, meat quality, shelf life

\section{INTRODUCTION}

Research into novel and underutilized feed resources for ruminant production and shelf life enhancement is paramount to sustainability of livestock and meat industries (1). Among the novel alternatives to conventional feed resources are hemp (Cannabis sativa L.) by-products (i.e., seed, oil, oilseed cake, hulls, and leaves) $(2,3)$. Growing legalization and demand are anticipated to increase global production of hemp and its by-products $(4,5)$. As a consequence, the feed and meat industries could benefit provided hemp by-products can be valorised as feed ingredients and biopreservatives (Figure 1).

There are few reports on incorporation of hemp by-products into ruminant diets $(6,7)$. In Europe, inclusion of hempseed cake (HSC) has been restricted to $<50 \mathrm{~g} / \mathrm{kg}$ DM in ruminant diets (2). In other jurisdictions such as North America, feeding of hemp by-products awaits approval and will be done based on applications for individual by-products $(8,9)$. This is partly because of limited data on the bioavailability of dominant bioactive compounds of Cannabis species (i.e., tetrahydrocannabinol, THC, and cannabidiol, CBD) in ruminant animals (2) and the known psychoactive effects of THC in humans (10). In addition, there is limited knowledge on the bio-efficacy of these and other bio-actives in a meat matrix (2). The present review explores the composition, bioavailability and bioefficacy of hemp by-product nutrients and bioactives in ruminant meat production and preservation. Challenges and opportunities for valorisation of hemp by-products for meat production and shelf life extension are also discussed. 


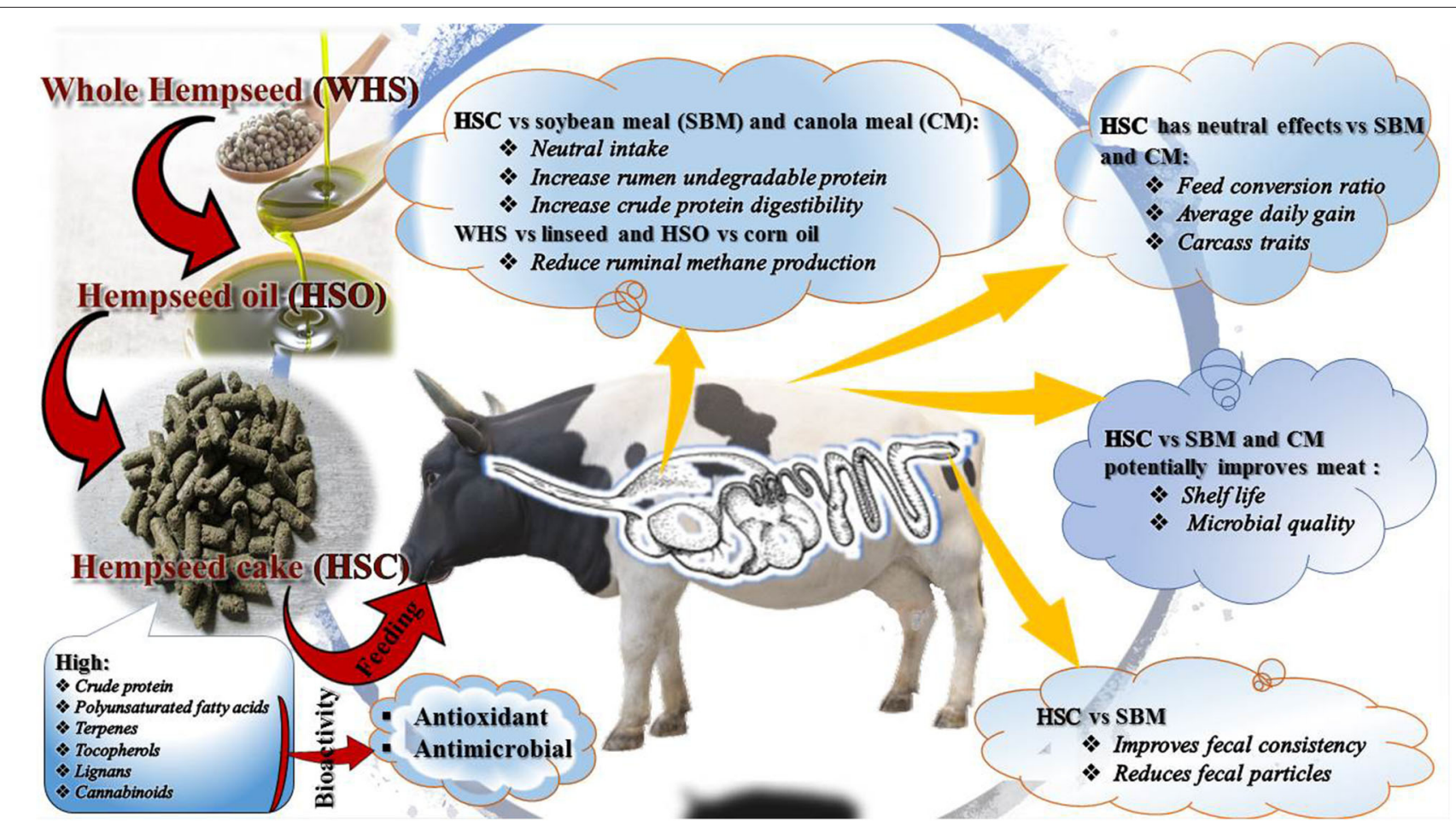

FIGURE 1 | Valorisation of hemp by-products nutrients and bioactive compounds in ruminants.

TABLE 1 | Global production of hemp and its by-products

\begin{tabular}{|c|c|c|c|c|c|}
\hline \multirow[b]{2}{*}{ Country } & \multirow[b]{2}{*}{$\begin{array}{c}\text { Area } \\
\text { harvested } \\
\text { (ha) }\end{array}$} & \multicolumn{4}{|c|}{ Production (tons) } \\
\hline & & Seed & Oil* & Cake* $^{\star}$ & Leaf meal ${ }^{\star *}$ \\
\hline France & 16,511 & 125,362 & 43,877 & 81,485 & 170,063 \\
\hline Russian & 4,691 & 2,117 & 741 & 1,376 & 48,317 \\
\hline China & 4,342 & 11,822 & 4,138 & 7,684 & 44,723 \\
\hline Chile & 2,660 & 1,533 & 537 & 996 & 27,398 \\
\hline Hungary & 1,606 & 390 & 137 & 254 & 16,542 \\
\hline Ukraine & 1,133 & 596 & 209 & 387 & 11,670 \\
\hline Romania & 799 & 84 & 29 & 55 & 8,230 \\
\hline Iran & 193 & 198 & 69 & 129 & 1,988 \\
\hline Spain & 140 & 750 & 263 & 488 & 1,442 \\
\hline Poland & 59 & 28 & 10 & 18 & 608 \\
\hline Turkey & 6 & 3 & 1.05 & 1.95 & 61.8 \\
\hline
\end{tabular}

${ }^{\star}$ Oil was estimated at $35 \%$ seed content and resultant cake (11).

** Leaf meal was estimated at 10.3 tons/ha (12).

Source: (13).

\section{GLOBAL HEMP PRODUCTION AND UTILIZATION}

Globally, the FAO estimates of 32 square kilometers $\left(\mathrm{km}^{2}\right)$ of hemp are harvested including 143 metric tons (MT) hempseed,
50 MT seed oil, 93 MT cake, and 331 MT leaves are produced mainly from France, China, and Chile (Table 1), but this does not include Canada or the USA, which are also major producers with an estimated $315 \mathrm{~km}^{2}$ (23) and $1,160 \mathrm{~km}^{2}$ (24) under cultivation, respectively. Overall, scant data exists on hemp or byproducts production, especially in Africa. Hemp is a multifaceted plant commonly cultivated for fiber and oil, although other components of the plant might have beneficial uses as medicine $(25,26)$. Primary uses of hemp are determined by variety and region of origin (4). The majority of hemp varieties are cultivated for seed production, of which, hempseed oil is the primary valuable output $(14,15)$. On average, hempseed has $30-35 \%$ seed oil, that is extracted only by cold pressing (11), with HSC being the main solid by-product of oil extraction. Cold-press method preserves physical and chemical quality of oil (15). A small proportion (i.e., $0.4-10 \%$ ) of the oil is retained in HSC after extraction (15). Hemp stems are utilized in the textile, livestock (i.e., beddings), and automotive industries as they utilize a large amount of fiber $(11,27)$. Hemp leaves and inflorescences are sources of bioactive compounds used in pharmaceuticals and human foods $(11,28)$.

Hemp varieties are rarely used for medicinal purposes because they have low THC content $(<0.2 \%)$ (11). Hemp production is low as it is often confused with marijuana which is illegal to cultivate in most countries $(14,15)$. However, many countries have legalized the commercial production of hemp and utilization of its by-products (26). For example, South Africa recently passed a law to license cultivation and processing of hempseed using varieties with $<0.001 \%$ THC (29). The 
liberalization of hemp legalization by many countries is likely to increase oil production, and consequent utilization of its byproducts (i.e., HSC and leaf meals). This increase in oil, HSC, and leaf meal could potentially be beneficial to hemp processing, animal feed and meat industries. Currently, hemp by-products are not recognized as commercial livestock feed ingredients in most countries, even though some have come up with inclusion guidelines for livestock diets (2). Generally, limited literature exists on the utilization of hemp by-products except for the oil $(11,30)$. The value of hemp by-products as animal feed lies in the nutritional and phytochemical contents of HSC, especially when leaf production is limited.

\section{NUTRIENT COMPOSITION OF HEMP BY-PRODUCTS}

Chemical composition of hemp by-products is largely influenced by variety, pressing, and seed treatment methods $(15,31)$. However, hemp by-product chemical composition is generally similar to soybean meal (SBM) except for hurds, which contains extremely low CP and ether extract (EE; Table 2). The CP content of hemp by-products is greater than the endorsed dietary requirements for maintenance $(60-110 \mathrm{~g} / \mathrm{kg} \mathrm{CP} \mathrm{DM})$ and growth (120-180 g/kg CP DM) of ruminants $(32,33,36)$. Hemp byproducts have a well-balanced amino acid profile comparable to SBM, with tryptophan as a limiting amino acid (Table 2). However, hemp by-products are deficient in growth-limiting amino acids including methionine (1.8 and $2.0 \% \mathrm{CP}$ ) and lysine (6.4 and $6.8 \% \mathrm{CP}$ ) as per the body requirements for goats and cattle, respectively $(36,37)$. The EE, neutral detergent fiber (NDF) and acid detergent fiber (ADF) of hempseed, cake, and hulls are greater than SBM (Table 2). The difference in EE content of hemp by-products and SBM could be attributed to the oil extraction method. Solvent extraction has greater oil extraction efficiency than cold press which leaves about $7 \%$ of the oil in the cake (38). The EE value of hempseed, cake and hulls is thus about 2.5 times greater than the EE ( $<50 \mathrm{~g} / \mathrm{kg} \mathrm{DM})$ recommended for optimal ruminant production (39). This high EE content might affect the inclusion level of hemp by-products in ruminant diets.

High inclusion levels of hemp by-products have been recommended for ruminants based on NDF content (2). More so, hemp by-products are within the recommended dietary NDF content of $150-300 \mathrm{~g} / \mathrm{kg}$ DM required for optimal ruminant production $(40,41)$. Lignin content of whole hempseed and HSC has been reported to be $112-117 \mathrm{~g} / \mathrm{kg} \operatorname{DM}(16,42)$. NRC (36) suggested that ruminant dietary lignin content above $40 \mathrm{~g} / \mathrm{kg} \mathrm{DM}$ will probably decrease DM intake and digestibility. High lignin content of HSC could be attributed to the hull (30-46\% of seed) remains in the cake during oil extraction $(4,34,38)$. More so, hulls contain the highest (65\%) fiber portion of the hempseed $(5,15)$. In hempseed, lignin is only found in the hulls $(4)$.

Metabolisable energy (ME) of HSC ranges from 9.21 to 13.01 $\mathrm{MJ} / \mathrm{kg} \mathrm{DM}(6,17)$. These values exceed the average requirements for maintenance (i.e., 0.424, 0.401, and $0.497 \mathrm{MJ} \mathrm{ME} / \mathrm{kg} \mathrm{BW}^{0.75}$ ) and growth $(0.03,0.015$, and $0.016 \mathrm{MJ} \mathrm{ME} / \mathrm{g}$ of weight gain) for

TABLE 2 | Chemical (g/kg DM, Mean \pm SD) and amino acid (\%, Mean \pm SD) composition of hemp by-products.

\begin{tabular}{|c|c|c|c|c|c|c|}
\hline \multirow[t]{2}{*}{ Chemical composition } & \multicolumn{5}{|c|}{ Hemp by-product } & \multirow{2}{*}{$\begin{array}{l}\text { Soybean } \\
\text { meal }\end{array}$} \\
\hline & Seed & Cake & Hulls & Hurds & Leaves & \\
\hline DM & $928 \pm 16.52$ & $929 \pm 16.1$ & $949 \pm 18$ & 963 & 931 & $906 \pm 9.9$ \\
\hline $\mathrm{CP}$ & $260 \pm 48.64$ & $341 \pm 50.4$ & $127 \pm 37$ & 32.0 & 238 & $503 \pm 18.4$ \\
\hline EE & $290 \pm 111.24$ & $116 \pm 15.5$ & $103 \pm 58$ & 0.08 & 200 & $40 \pm 15.9$ \\
\hline NDF & $328 \pm 28.92$ & $395 \pm 40.7$ & $649 \pm 93$ & 900 & - & $125 \pm 17.6$ \\
\hline ADF & $230 \pm 15.72$ & $275 \pm 19.3$ & $502 \pm 61$ & 789 & - & $89 \pm 10.2$ \\
\hline Ash & $57 \pm 10.85$ & $68 \pm 3.44$ & $39 \pm 60$ & - & 112 & $69 \pm 5.5$ \\
\hline \multicolumn{7}{|l|}{ Amino acid } \\
\hline Arginine & $2.42 \pm 0.26$ & $4.11 \pm 0.69$ & $0.94 \pm 0.80$ & - & 4.32 & $3.63 \pm 0.21$ \\
\hline Cystine & $0.44 \pm 0.06$ & $0.74 \pm 0.15$ & $0.18 \pm 0.06$ & - & 0.79 & $0.71 \pm 0.06$ \\
\hline Histidine & $0.58 \pm 0.06$ & $0.98 \pm 0.19$ & $0.25 \pm 0.15$ & - & 2.21 & $1.27 \pm 0.08$ \\
\hline Isoleucine & $0.90 \pm 0.11$ & $1.52 \pm 0.23$ & $0.39 \pm 0.14$ & - & 3.23 & $2.47 \pm 0.45$ \\
\hline Leucine & $1.58 \pm 0.16$ & $2.47 \pm 0.23$ & $0.71 \pm 0.27$ & - & 7.1 & $3.79 \pm 0.18$ \\
\hline Lysine & $0.91 \pm 0.09$ & $1.39 \pm 0.27$ & $0.33 \pm 0.16$ & - & 3.84 & $3.11 \pm 0.16$ \\
\hline Methionine & $0.60 \pm 0.08$ & $0.93 \pm 0.25$ & $0.18 \pm 0.12$ & - & 0.89 & $0.65 \pm 0.06$ \\
\hline Phenylalanine & $1.09 \pm 0.16$ & $1.70 \pm 0.30$ & $0.53 \pm 0.09$ & - & 3.94 & $2.68 \pm 0.46$ \\
\hline Threonine & $1.07 \pm 0.22$ & $1.42 \pm 0.23$ & $0.36 \pm 0.13$ & - & 2.26 & $1.96 \pm 0.10$ \\
\hline Tryptophan & $0.24 \pm 0.06$ & $0.41 \pm 0.10$ & $0.06 \pm 0.04$ & - & - & $0.71 \pm 0.06$ \\
\hline Valine & $1.21 \pm 0.14$ & $2.01 \pm 0.30$ & $0.60 \pm 0.31$ & - & 3.91 & $2.46 \pm 0.30$ \\
\hline
\end{tabular}

Sources: $(2,3,6,7,14-22)$ 
goats, sheep, and cattle, respectively $(32,36)$ when HSC fed at $2 \%$ BW, hence, HSC could serve well as a ruminant feedstuff. The mineral elements of hemp by-products are lower than ruminant maintenance requirements though the whole seed meets micromineral requirements (Table 3). Although their mineral content is not well-researched, all hemp by-products except hurds can be used as potential feed ingredients in ruminant diets.

\section{PHYTOCHEMICAL COMPOSITION OF HEMP BY-PRODUCTS}

Hemp has a total of 538 identified bioactive compounds dominated by terpenoids ( $>120)$, cannabinoids $(>70)$ and polyphenols $(11,36,43)$. Resin glands on trichomes or head cells of glandular hair are major production sites for terpenoids, cannabinoids, and polyphenols $(26,28)$. Terpenoids, cannabinoids, polyphenols, and fatty acids (FA) comprise classes of bioactive compounds of great interest in hempseed and its byproducts due to their plethora of health-promoting properties $(11,43)$. Although cannabinoids including CBD and THC are not synthesized in seeds, they are transferred from resins, leaves and flowers into oil and oilseed cake during oil extraction $(11,27)$. Hence, cleaning and de-hulling of seeds are executed before oil extraction, to minimize cannabinoids transfer into oilseed by-products (11). Palade et al. (44) found traces of cannabinoids (i.e., $164.4 \mathrm{mg}$ catechin equivalents (CE)/100 g of feed) in pig diets formulated with whole hempseed. Higher content of cannabinoids in hemp seed extracts is, therefore, a sign of contamination or use of medicinal cannabis varieties (27).

Other phytochemical constituents of hemp by-products include condensed tannins (CT), alkaloids, phenols, lignanamides, and tocopherols $(35,45)$. The CT are low in hempseed and HSC (Table 4). Hemp leaves might contain higher contents of CT since the concentration of bioactive compounds in hemp plant chronologically decreases from flowers, leaves, stems, seed to the roots (27). However, there is no available literature on CT of hemp leaves. Turner et al. (55) suggested that hempseed by-products contain alkaloids and this was confirmed by Yan et al. (56), but their contents have not yet been determined.

Hempseed is a good source of lignan $(320 \mathrm{mg} / \mathrm{kg} \mathrm{DM})(57,58)$. It is dominated by lignanamides (cannabisin A) while HSC and inflorescences are dominated by flavanols (i.e., catechin; Table 4). More so, 99\% of lignans are found in hempseed hulls, hence, dehulled hempseeds and the resultant cake have little lignan $(57,59)$. Syringaresinol content of hempseed hull $(280 \mathrm{mg} / \mathrm{kg}$ $\mathrm{DM}$ ) is the highest of any dietary source (57). Since HSC is produced from hulled seeds, its lignan content is expected to be low. However, there is limited literature on the lignan contents of HSC and leaves.

The tocopherol profile of hemp by-products is dominated by $\gamma$-tocopherol (Table 4), which is the tocopherol with the strongest antioxidant activity, but $\alpha$-tocopherol is regarded as the most vital form $(42,60,61)$. The $\alpha$-tocopherol content of hemp by-products exceed dietary requirements for physiological function of growing small ruminants $(10-20 \mathrm{mg} / \mathrm{kg} \mathrm{DM})$ and cattle $(15-60 \mathrm{mg} / \mathrm{kg})(33,62)$, but below values $(270-287 \mathrm{mg} / \mathrm{kg})$ required to extend meat shelf life $(63,64)$.

Fatty acids in hempseed, oil, and cake contain $65-80 \%$ PUFA with the major FAs being linoleic (18:2 n-6) followed by $\alpha$ linolenic acid (18:3n-3) and oleic acid (C18:1 n-9; Table 4). This makes hempseed and its by-products an excellent source of essential fatty acids, with an omega 6 to omega 3 fatty acid ratio of $\sim 3.3: 1$, which is similar to canola oil while providing a more healthful balance than soybean oil (7:1). Phytate (22.5 $\mathrm{mg} / \mathrm{g})$ and glucosinolates $(3.8 \mu \mathrm{mol} / \mathrm{g})$ are the most abundant anti-nutritional factors in HSC (18). However, at these low concentrations, phytate, and glucosinolates are unlikely to have adverse effects on ruminants $(65,66)$. Beneficial nutritional and

TABLE $3 \mid$ Hemp by-products mineral content and ruminant requirements (Mean \pm SD).

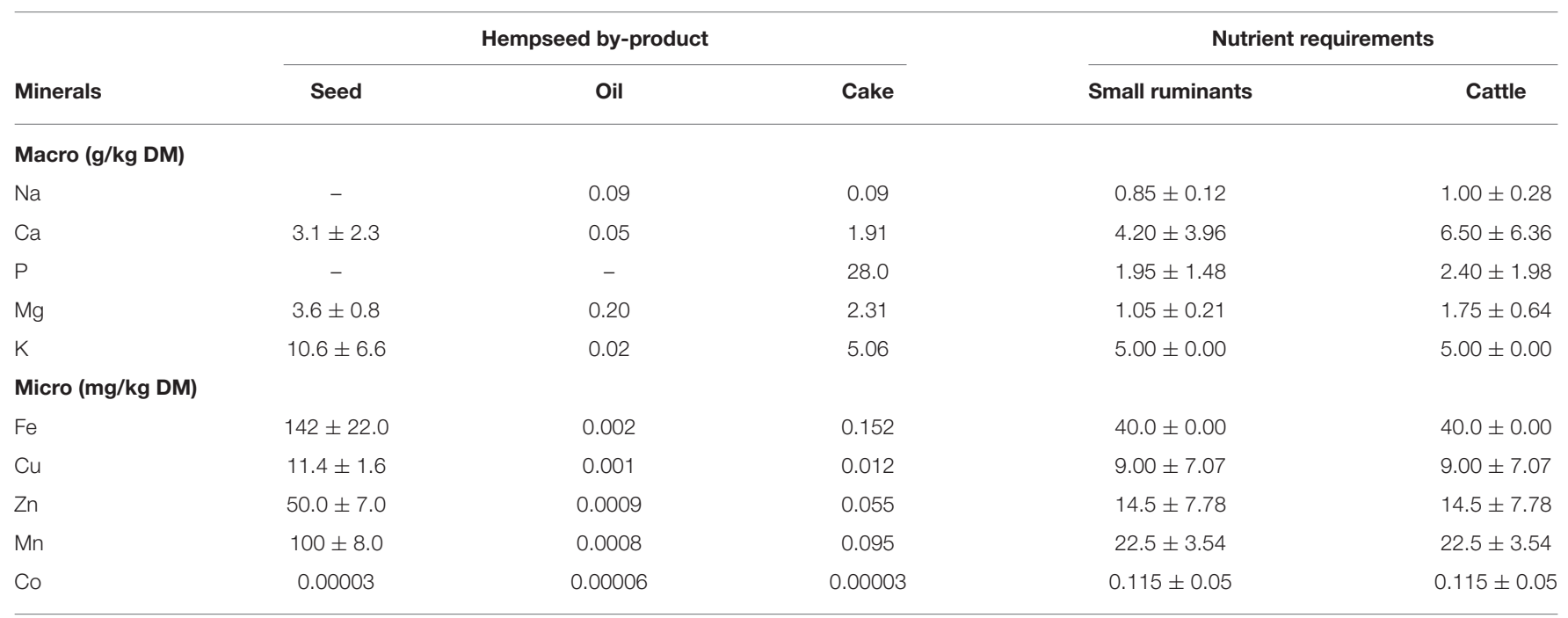

Sources: (16, 31-35). 
TABLE 4 | Bioactive compounds and in vitro bioactivity profile of hemp by-products (Means \pm SD).

\begin{tabular}{|c|c|c|c|c|}
\hline & \multicolumn{4}{|c|}{ Hemp by-product } \\
\hline & Seed & Oil & Cake & Inflorescence \\
\hline \multicolumn{5}{|l|}{ Phenolics (mg/kg DM) } \\
\hline Condensed tannins & $1.10 \pm 0.04$ & - & $1.64 \pm 1.87$ & \\
\hline Catechin & - & $498 \pm 35.9$ & $0.05 \pm 0.03$ & $51.1 \pm 48.4$ \\
\hline N-trans-caffeoyltyramine & $490 \pm 484$ & $152 \pm 11.2$ & - & $38.2 \pm 53.8$ \\
\hline p-hydroxybenzoic acid & $21.0 \pm 12.7$ & $78.6 \pm 8.00$ & $0.002 \pm 0.001$ & - \\
\hline Cannabisin A & $1,051 \pm 764$ & - & - & $1.44 \pm 2.02$ \\
\hline Cannabisin B & - & $64.9 \pm 1.94$ & - & $0.45 \pm 0.07$ \\
\hline Cannabisin C & - & - & - & $0.19 \pm 0.27$ \\
\hline ferulic acid & - & $47.4 \pm 5.37$ & - & $19.3 \pm 23.1$ \\
\hline Protocatechuic acid & $10.0 \pm 8.49$ & $28.2 \pm 2.47$ & - & - \\
\hline TPC (mg GAE/g) & $26.2 \pm 36.0$ & $1.23 \pm 0.69$ & $1.35 \pm 1.87$ & $31.5 \pm 29.7$ \\
\hline \multicolumn{5}{|l|}{ Tocopherols (mg/100g) } \\
\hline$\gamma$-tocopherol & $1,239 \pm 1,076$ & $516 \pm 400$ & $358 \pm 28.9$ & - \\
\hline$\alpha$-tocopherol & $44.1 \pm 3.54$ & $16.1 \pm 5.33$ & $29.7 \pm 2.76$ & - \\
\hline$\delta$-tocopherol & $281 \pm 427$ & $12.0 \pm 4.00$ & $11.3 \pm 13.6$ & - \\
\hline \multicolumn{5}{|l|}{ Fatty acid ( $\%$ Total FA) } \\
\hline Palmitic acid & $6.19 \pm 2.12$ & $6.44 \pm 1.99$ & $7.54 \pm 1.02$ & - \\
\hline Stearic acid & $2.61 \pm 0.89$ & $2.75 \pm 0.84$ & $3.21 \pm 0.55$ & - \\
\hline Oleic acid & $11.6 \pm 4.49$ & $12.2 \pm 4.49$ & $12.7 \pm 0.39$ & - \\
\hline Linoleic acid & $48.8 \pm 17.6$ & $50.2 \pm 17.0$ & $54.6 \pm 1.56$ & - \\
\hline$\gamma$-linolenic & $2.61 \pm 1.14$ & $2.60 \pm 1.16$ & $2.97 \pm 0.19$ & - \\
\hline$\alpha$-linolenic & $14.9 \pm 6.35$ & $15.2 \pm 6.47$ & $17.2 \pm 2.33$ & - \\
\hline Total polyunsaturated fatty acid & $66.7 \pm 24.5$ & $68.3 \pm 22.7$ & $75.4 \pm 6.61$ & - \\
\hline \multicolumn{5}{|l|}{ Antioxidant capacity } \\
\hline DPPH (\% inhibition) & $45.8 \pm 8.13$ & $46.8 \pm 0.00$ & $31.1 \pm 32.4$ & $52.6 \pm 35.4$ \\
\hline ORAC ( $\mu \mathrm{mol}$ TE/g) & $127 \pm 5.0$ & - & $28.2 \pm 6.19$ & - \\
\hline
\end{tabular}

TPC, total phenolic content; DPPH, 1,1-diphenyl-2-picrylhydrazyl; ORAC, oxygen radical absorbance capacity; GAE, gallic acid equivalent; TE, trolox equivalent. Sources: $(3,18,35,45-54)$.

phytochemical profiles of hemp by-products highlighted above provide a possible avenue for their inclusion in ruminant diets as protein sources, antioxidants and antimicrobials.

\section{IN VITRO BIOACTIVITY OF PHYTOCHEMICALS IN HEMP BY-PRODUCTS}

\section{Antioxidant Activity}

Hemp by-products contain potent antioxidants (Table 4), which decreases from flowers to leaves (27). The antioxidant capacity of hemp by-products, as measured by 1,1-diphenyl-2picrylhydrazyl (DPPH) values (Table 4), are comparable to $\alpha$ tocopherol (33.3-70\%), a potent natural antioxidant commonly used commercially $(67,68)$. Hemp by-product oxygen radical absorbance capacity (ORAC) values are, however, lower than $\alpha$ tocopherol (1,293 $\mu \mathrm{m} \mathrm{TE/g)} \mathrm{(69),} \mathrm{and} \mathrm{ORAC} \mathrm{values} \mathrm{are} \mathrm{thought}$ to be more reflective of antioxidant capacity in biological systems (70).

Phenol amides (i.e., $N$-trans-caffeoyl-tyramine), lignanamides (i.e., cannabisin A, B, and C) $(46,71)$, tocopherols $(42,61)$ and CBD (11) are the major elements contributing to the antioxidant capacity of hempseed by-products. Chen et al. (71) and Irakli et al. (46) narrowed this list to N-trans-caffeoyltyramine, cannabisin $\mathrm{A}, \mathrm{B}$, and $\mathrm{C}$ as the major antioxidant phenolic compounds of hemp. Furthermore, Izzo et al. (45) confirmed that inflorescent extracts from hemp varieties with a high content of $\mathrm{N}$-trans-caffeoyl-tyramine, cannabisin $\mathrm{A}$, and B were more potent antioxidants. Overall, the current review highlights that hemp by-products are a rich and diverse source of potent antioxidants. However, there are still gaps in how this antioxidant potential may influence animal production, meat quality, shelf life, and sensory attributes. Further research is, therefore, required to ascertain their potency and mechanism of action during production, processing, storage/aging, display, and cooking through to consumption. 


\section{Antimicrobial Activity}

Essential oil extracts from the whole hemp plant material exhibit antimicrobial activity in most bacterial habitats from human, animal, and food sources, but are active against fungi (25, 72). Hempseed extracts have antimicrobial inhibitory effect on pathogenic bacterial strains of human origin (73). The highest hemp antibacterial activity is found in inflorescences $(26,74)$. Inflorescences are sites for the production of majority of bioactive compounds of hemp as they have resin glands $(26,28)$. With low THC and CBD contents in hempseed, antibacterial capacity of hempseed by-products could be attributed to terpenes, polyphenols and alkaloids. Terpinolene has been reported to be the main bioactive compound responsible for bacterial inhibitory activity of hemp inflorescence essential oil (74). Just like other monoterpenes, terpinolene disrupts bacterial cell membrane and wall integrity $(75,76)$. Generally, monoterpenes interact with bacterial cell membrane phospholipids, which results in increased permeability and leakage of cell content and ultimately cell death $(75,76)$. More scientific research into additive, synergic, and antagonistic antimicrobial effects of bioactive compounds in hemp by-products will be important to promote their use in the feed and meat industries.

Numerous studies have reported that polyphenols and alkaloids exert antibacterial properties through binding to the cell membrane hence inhibiting cell functions $(77,78)$. Overall, current literature shows that hemp whole plant essential oil extracts have good antimicrobial activity. However, to the authors' knowledge, no literature exists on the antimicrobial properties of various bioactive compounds found in hemp byproducts and merits further investigation.

\section{BIOAVAILABILITY OF BIOACTIVE COMPOUNDS OF HEMP BY-PRODUCTS IN RUMINANTS}

Information on bioavailability of bioactive compounds is paramount in understanding their intake, digestion, absorption, metabolism, and excretion (80). That will, in turn, enable traceability of bioactive compounds and their derivatives in animal products (i.e., meat and milk). Bioavailability entails describing or quantifying the specific nutrient or bioactive available at a target organ/blood circulatory system level $(81,82)$. Bioavailability is an integral process that has five steps which include release from feed matrix in the gastrointestinal tract (GIT) (i.e., liberation), absorption, distribution, metabolism, and excretion.

To date, there is no literature on how digestion of hemp by-products in ruminants affects bioavailability of terpenes, cannabinoids, lignans, and polyphenols (Figure 1). Overall, terpenes and CBD are volatile compounds easily released from the feed matrix, absorbed and excreted unchanged $(10,83)$. Terpenes digestion and absorption begins during mastication and rumination and continues throughout the GIT (83). Glucuride conjugates of CBD were detected in urine and feces as the second most abundant component next to intact CBD in animal studies (10). These findings could imply that their metabolism during and/after uptake follows conjugation (phase II) processing with hydrophilic compounds such as glycine and glucuronic acid in the liver $(28,83)$. Less of phase II reaction of substances might occur in the gut or blood, but the majority occurs in the liver and bile due to abundance of enzymes involved in this reaction (28).

Metabolism pathways for terpenes and CBD are believed to be the same since the two compounds and their derivatives possess similar physical and chemical properties (27, 84). Previous studies demonstrated the transfer of dietary terpenes to ruminant meat (85-87). Since terpenes are fat-soluble, adipose tissue is the main depot assessed when studying between-diet effects in ruminants $(87,88)$. Cannabinoid conjugates were observed in major tissues of Large White pigs injected with THC (200 $\mu \mathrm{g} / \mathrm{kg}$ ) (84). Cannabinoids and their derivatives have also been detected in milk, feces, and urine of lactating ewes injected with THC as well as in fecal and urine samples of suckling lambs (89). Some studies concluded that cannabinoids are eliminated from the body after a short period $(<48 \mathrm{~h})$, even with chronic exposure $(10,84)$.

Kuhnle et al. (90) reported lignans in beef $(6-16 \mu \mathrm{g} / 100 \mathrm{~g}$ wet weight) and lamb (4-17 $\mu \mathrm{g} / 100 \mathrm{~g}$ wet weight). Ruminal biohydrogenation leads to the conversion of dietary lignans to enterolactones, which are absorbed from the gut and deposited in tissues including milk (91) and meat (90). Manipulation of dietary phenolic compounds has been confirmed to change their contents in meat $(92,93)$. However, not all phenolics found in the diet are incorporated in similar amounts in meat. Moñino et al. (92) observed that among the 11 major phenols identified in rosemary containing diets fed to lambs, only 3 (rosmarinic acid, carnosol, and carnosic acid) significantly increased with dietary inclusion levels of rosemary. Some of the phenolics in the diet are lost in feces or biotransformed before urinary excretion $(92,94)$.

The $\alpha$-tocopherol content of meat from steers fed HSC diets was reported to be $2.55 \mathrm{mg} / 100 \mathrm{~g}$ lipid (95). Dietary $\alpha$-tocopherols are non-degradable in the rumen (96), hence, availed in the small intestines for absorption and assimilation into adipose tissue and cell membranes to exert antioxidant activities $(97,98)$. Overall, bioefficacy of bioactive compounds is closely related to the amount released from the feed matrix, absorbed, and assimilated into tissues $(80,99)$. In this case, response/efficacy of bioactive compounds in meat derived from ruminants fed hemp by-products diets is closely related to their bioavailability. Understanding bioavailability of hemp by-products bioactive compounds is, therefore, essential in establishing their optimum inclusion levels in ruminant diets that efficiently improve meat production and quality.

\section{EFFECT OF HEMP BY-PRODUCTS ON RUMINANT NUTRITION}

\section{Nutrient Intake}

A survey by Bamikole and Ikhatua (100) indicates hemp leaves have been fed as an appetite stimulant in small ruminants. Feeding HSC either had neutral or positive effects on dry matter intake (DMI; Table 5). For example, feeding $1 \mathrm{~kg}$ or 1.4 
TABLE 5 | Nutrient intake (Mean \pm SD) of calves, steers and lambs fed hempseed cake, soybean, or canola meal diets.

\begin{tabular}{|c|c|c|c|c|c|c|c|c|c|}
\hline \multirow[b]{2}{*}{ Nutrient intake (kg DM) } & \multicolumn{2}{|c|}{ Calves } & \multirow[b]{2}{*}{ SEM } & \multicolumn{2}{|c|}{ Steers } & \multirow[b]{2}{*}{ SEM } & \multicolumn{2}{|c|}{ Lambs } & \multirow[b]{2}{*}{ SEM } \\
\hline & HSC & SBM & & HSC & SBM & & HSC & $\mathbf{C M}$ & \\
\hline DM & 5.00 & 4.55 & 0.11 & 11.2 & 10.6 & 0.25 & 1.46 & 1.34 & 0.7 \\
\hline NDF & 1.68 & 1.28 & 0.02 & 4.17 & 3.7 & 0.09 & - & - & - \\
\hline Starch & 1.43 & 1.55 & 0.02 & 3.36 & 3.47 & 0.09 & 0.38 & 0.39 & 0.02 \\
\hline $\mathrm{CP}$ & 0.83 & 0.64 & 0.01 & 1.43 & 1.24 & 0.02 & 0.14 & 0.12 & 0.007 \\
\hline Fat & 0.16 & 0.09 & 0 & 0.26 & 0.18 & 0.4 & - & - & - \\
\hline $\mathrm{ME}^{*}$ & 58.6 & 53.7 & 1.25 & 134 & 127 & 3.1 & 11.3 & 11.6 & 0.45 \\
\hline
\end{tabular}

*MJ/kg DM; Calves, 6-8 weeks of age weighing $96 \pm 21$ kg; Steers, 13-15 months of age weighing $365 \pm 28$ kg; HSC, hempseed cake; SBM, soybean meal; CM, canola meal; DM, dry matter; NDF, neutral detergent fiber; CP, crude protein; ME, metabolisable energy; SEM, Standard error of mean.

Source: $(6,7,79)$.

$\mathrm{kg} / \mathrm{animal} /$ day of HSC resulted in an increase in DMI for dairy calves, but not for steers (Table 5). The DMI increase for the dairy calves was attributed to reduced NDF rumen fill in HSC compared to SBM. Mustafa et al. (7) reported no differences in DMI of lambs fed diets containing $200 \mathrm{~g} \mathrm{HSC} / \mathrm{kg} \mathrm{DM}$, while Karlsson et al. (17) and Karlsson and Martinsson (79) included HSC in dairy cows (up to $320 \mathrm{~g} / \mathrm{kg} \mathrm{DM}$ ) and lambs (218 g/kg DM) diets and recorded an increase in DMI. These inconsistences in DMI could be attributed to different inclusion levels, differences in composition of basal diets and animal species used across studies and deserve further investigation.

Inclusion of HSC ( $320 \mathrm{~g} / \mathrm{kg} \mathrm{DM})$ in ruminant diets increased NDF and CP intake $(6,7,17)$. It is of importance to note (79) reported that lambs fed HSC diet were able to attain required $\mathrm{CP}$ intake of $127 \mathrm{~g} / \mathrm{d}$ to attain an average daily gain (ADG) of $250 \mathrm{~g} / \mathrm{d}$ (32). It is not immediately clear how HSC and other hemp by-products influence nutrient intake when fed solely or in combination with other protein sources. This creates an opportunity for further studies on inclusion of hemp by-products in ruminant diets.

\section{Nutrient Digestibility}

Hempseed cake has a low effective degradability of DM (EDDM) when compared to canola meal and SBM (Table 6). Dry matter digestibility is likely to be lesser for HSC vs. canola meal and SBM. However, HSC has been reported to increase rumen retention time and improve the rumen environment for microbial degradation as evidenced by fecal consistency scores (6). The CP solubility and degradability of HSC is low compared to canola meal and/or SBM (Table 6). However, potentially degradable protein portion of HSC is higher than canola meal and SBM. The aforementioned aspects result in increased ruminal passage of undegraded dietary protein (UDP). The UDP of HSC is highly digestible in the duodenum as compared to canola meal (7). Additionally, UDP and intestinal digestibility of HSC can be increased by moist heat treatment up to $130^{\circ} \mathrm{C}(109)$.

Digestibility coefficients of HSC are comparable to SBM and canola meal (Table 6). Hempseed cake has low NDF degradability (in sacco) because of its high indigestible NDF (iNDF; $409 \mathrm{~g} / \mathrm{kg} \mathrm{DM}$ ) fraction $(17,110)$ which might be different in vivo. Although HSC has high EE (Table 2), which contributes to $\mathrm{ME}$, fermentable energy to facilitate microbial growth is derived from fermentable carbohydrates (111).

Overall, hempseed oil has lower ruminal fermentation parameters compared to soybean and canola oil (Table 6). Total volatile fatty acids (VFA) can be as high as $200 \mathrm{mM}$ just after feeding or decrease as low as $30 \mathrm{mM}$, however, its normal range is $70-120 \mathrm{mM}$ (112). Low total VFA (37 mM) from hempseed oil could be an indicator of depressed rumen formation. Hempseed oil has a high PUFA content (Table 4), which may have an inhibitory effect on ruminal fibrolytic bacteria $(113,114)$. Hempseed oil reduces ruminal acetate production, which is generally an indicator of decreased fiber digestibility (101). Unaffected propionate production is an indicator of little or no influence on carbohydrate degradation (101). Hempseed cake has potential to maintain nutrient digestibility when used to replace other high-protein feedstuffs while hempseed oil depresses ruminal fermentation when added at levels $<3.0 \mathrm{~g} / \mathrm{kg}$ DM (101).

\section{Nitrogen and Methane Emissions}

To the authors' knowledge, there are only two studies that evaluated in vitro ruminal nitrogen and methane production inhibition of hempseed by-products $(101,115)$. Findings of these studies showed that both whole hempseed and oil had neutral effects on ruminal ammonia-nitrogen production. Whole hempseed was $8 \%$ more effective at reducing methane than linseed but comparable to coconut oil (115). Embaby et al. (101) recorded a $10 \%$ decrease in methane production for hempseed oil compared to corn oil. Methane production reduction is attributed to high PUFA content in hempseed oil, which suppresses protozoa and acts as hydrogen sink through biohydrogenation $(115,116)$, with $\alpha$-linolenic acid being a more potent anti-methanogen than linoleic acid (117). Whole hempseed is, however, more effective than oil at inhibiting methanogens since it has more terpenes, polyphenols and lignans, which are more toxic to methanogens than PUFA $(118,119)$. These compounds accumulate in cytoplasmic membranes as they are lipophilic thus disrupting methanogen cell membranes (118). 
TABLE 6 | Ruminal DM and CP degradation kinetics (Mean \pm SD) of common oilseed by-products.

\begin{tabular}{|c|c|c|c|}
\hline & Hempseed cake & Soybean meal & Canola meal \\
\hline \multicolumn{4}{|l|}{ Dry matter (DM) } \\
\hline Soluble (g/kg DM) & $82.4 \pm 3.36$ & $307 \pm 25.1$ & $253 \pm 34.6$ \\
\hline Degradable (g/kg DM) & $506 \pm 6.21$ & $684 \pm 17.4$ & $578 \pm 21.9$ \\
\hline Degradation rate (\%/h) & $2.40 \pm 0.08$ & $4.93 \pm 1.91$ & $5.13 \pm 1.03$ \\
\hline Effective degradability $(\mathrm{g} / \mathrm{kg})^{\mathrm{a}}$ & $248 \pm 2.81$ & $665 \pm 17.6$ & $528 \pm 49.6$ \\
\hline \multicolumn{4}{|l|}{ Crude protein (CP) } \\
\hline Soluble (g/kg CP) & $65.3 \pm 6.28$ & $206 \pm 48.6$ & $195 \pm 72.3$ \\
\hline Degradable (g/kg CP) & $901 \pm 3.33$ & $783 \pm 50.6$ & $715 \pm 155$ \\
\hline Degradation rate (\%/h) & $2.90 \pm 0.17$ & $4.77 \pm 1.83$ & $5.13 \pm 0.81$ \\
\hline Effective degradability $(\mathrm{g} / \mathrm{kg})^{\mathrm{a}}$ & $394 \pm 6.26$ & $610 \pm 30.6$ & $525 \pm 43.6$ \\
\hline Rumen-undegraded CP (g/kg CP) & $774 \pm 9.47$ & $415 \pm 22.3$ & $500 \pm 36.1$ \\
\hline Intestinally available CP (g/kg CP) & $654 \pm 11.9$ & - & $342 \pm 11.9$ \\
\hline Total available CP (g/kg CP) & $863 \pm 8.45$ & - & $869 \pm 8.45$ \\
\hline \multicolumn{4}{|l|}{ Digestibility coefficient (g/kg) } \\
\hline Dry matter & $640 \pm 18.8$ & $691 \pm 6.35$ & $683 \pm 36.6$ \\
\hline Organic matter & $665 \pm 18.3$ & $707 \pm 4.04$ & $704 \pm 28.2$ \\
\hline Neutral detergent fiber & $457 \pm 21.2$ & $460 \pm 20.1$ & $471 \pm 28.7$ \\
\hline Acid detergent fiber & $330 \pm 25.4$ & $424 \pm 28.3$ & $352 \pm 25.4$ \\
\hline Crude protein & $708 \pm 8.61$ & $689 \pm 36.4$ & $689 \pm 0.71$ \\
\hline Ruminal fermentation parameters & Hempseed oil & Soybean oil & Canola oil \\
\hline $\mathrm{pH}$ & $6.06 \pm 0.12$ & $6.36 \pm 0.62$ & $6.82 \pm 0.39$ \\
\hline NH3-N (mg/dL) & $7.96 \pm 0.84$ & $11.8 \pm 1.41$ & $11.0 \pm 1.46$ \\
\hline Total VFA (mM) & $37.4 \pm 2.70$ & $70.0 \pm 62.3$ & $78.7 \pm 0.37$ \\
\hline Acetate $(\mathrm{mM})$ & $14.8 \pm 1.04$ & $43.2 \pm 33.4$ & $42.3 \pm 4.74$ \\
\hline Propionate (mM) & $10.9 \pm 0.86$ & $16.7 \pm 17.6$ & $17.0 \pm 6.53$ \\
\hline Butyrate (mM) & $9.16 \pm 0.56$ & $9.51 \pm 10.7$ & $4.96 \pm 3.28$ \\
\hline Acetate: propionate & $0.76 \pm 0.10$ & $3.45 \pm 1.48$ & $2.90 \pm 1.01$ \\
\hline
\end{tabular}

${ }^{a}$ Calculated at a rumen flow rate of $5 \% / h$.

Sources: (7, 20, 101-108).

Although methane production is important in maintaining ruminal environment redox balance by providing a pathway for the excess pyruvate (112), it decreases the amount of ME obtained from a diet (69), hence, increasing energy required for meat production. The decrease in the concentration of methane produced may reduce atmospheric greenhouse gases and increase feed utilization efficiency as its emissions represent about $10 \%$ of gross energy loss from feed intake (120). Thus, reduction in methane emissions might maintain or improve animal performance by conserving energy which is redirected to animal growth (1). The limited available in vivo studies on antimethogenic effects of hemp by-products on animal performance warrants further research.

\section{Nutritional Disorders and Gut Health}

Terpenes in hemp by-products have antibacterial properties (74). Specifically, terpinolene and oxygenated monoterpenes have been reported to strongly suppress rumen microbial activity in in vitro studies (121). Of importance, ruminal antimicrobial effects of terpenes in vivo might be lower than in vitro as terpenes are easily absorbed along the entire GIT reducing their concentration (83). Inhibitory effect of terpenes on undesirable microbial activity is useful in reducing the rate of ruminal fermentation and degradation to avoid nutritional disorders such as bloat, acidosis, and ruminal parakeratosis (120).

Levels of CT in hemp by-products are below recommended (20-50 g CT/kg DM) values reported to prevent bloat, acidosis, and parakeratosis $(122,123)$, except for leaves. CT bind to dietary protein forming complexes thereby reducing protein solubility, hence decreasing the chance of developing a stable rumen foam $(123,124)$. Additionally, CT have a bactericidal effect on bloat causing bacteria such as Streptococcus bovis, which produces a dextran slime that increases rumen fluid viscosity, hence, bloating $(123,124)$. CT exert bactericidal effects by binding to plant protein, forming a CT-bacteria cell wall interaction, inhibiting carbohydrate fermentation and proteolytic rumen bacteria (123). 
In turn, CT can also improve conditions for cellulolytic bacteria, and avoid acidosis and parakeratosis $(123,125)$.

Condensed tannins in hempseed by-products have the potential for suppressing gastrointestinal tract (GIT) nematodes $(123,124,126)$ by inhibiting development of helminth eggs, reducing larvae, and adult motility as well as increasing the host animal's nutrient supply $(123,126)$. In that regard, hempseed by-products have the potential of improving gut health and preventing nutritional disorders among ruminants.

\section{GROWTH PERFORMANCE, CARCASS AND PHYSICOCHEMICAL MEAT QUALITY ATTRIBUTES OF RUMINANTS FED HEMP BY-PRODUCTS}

Karlsson and Martinsson (79) observed low growth performance of lambs fed HSC compared to canola meal. For this study, lambs on the HSC diet had a high CP intake with a low ME intake (Table 7). A ME and CP intake balance are required for the animal to gain weight (33). Excess CP intake creates an excretion burden, thereby affecting ADG and final live weight $(32,33)$. However, feeding whole hempseed to steers (19) or HSC to growing cattle (6), and dairy cows (17) did not affect final live weight or ADG. Lack of differences in animal growth when feeding HSC or SBM/canola meal to ruminants could be attributed to their similarity in chemical composition, nutrient intake and digestibility (Tables 2, 3).

Overall, feeding whole hempseed (14\% as fed) and HSC (1.4 $\mathrm{kg} / \mathrm{animal} /$ day) had neutral effects on carcass and meat quality traits in feedlot steers $(19,95)$ and lambs $(127)$. These findings are consistent with nutrient intake, digestibility, and animal growth data reported for the hempseed by-products in the current review. Similarly, feeding HSC resulted in comparable FA profiles with SBM and canola meal for beef and lamb meat, which was dominated by MUFA (oleic acid; C18:1) (Table 8) and these similarities are related to their dietary FA composition. Overall, HSC has comparable effects compared to SBM on ruminant growth performance, carcass, and physicochemical meat quality attributes. However, no information is available on volatile compounds or sensory attributes of meat from ruminants fed hemp by-products, and this requires investigation.

\section{AGING-PROTEOME CHANGES AND SHELF LIFE OF MEAT FROM RUMINANTS FED HEMP BY-PRODUCTS}

Proteomics is a relatively new technique in meat science that provides an avenue for understanding meat tenderness and color stability with respect to proteins involved at a molecular basis $(128,129)$. The technique does not only enable identification of myofibrillar proteins, protein, and glycolyticc enzymes involved in meat tenderness and color stability, but also allows establishment of the relationship between these proteins and bioefficacy of meat bioactive compounds $(128,129)$. Nassu et al. (130), for example, found that high muscle $\alpha$-tocopherol content protects meat discoloration at longer aging days $(21 \mathrm{~d})$, but does not affect meat tenderness. However, no proteomics was done in this study. The relationships between major meat bioactive compounds in hemp by-products and meat aging have not been investigated. Understanding how these antioxidant bioactive compounds interact with muscle protease system is crucial in establishing their impact on meat quality during aging.

In vitro studies show that hemp has antimicrobial properties $(25,74)$ due to its moderate contents of terpenes, CBD, $\alpha$ tocopherol, and polyphenols, which could be transferred into ruminant meat $(92,93)$. Hempseed increases meat PUFA content (19), which could make it susceptible to lipid oxidation. To authors' knowledge, no studies have evaluated the impact of hemp by-products in ruminant diets on myoglobin, lipid, and protein oxidation. However, feeding HSC increased total antioxidant capacity of sheep milk (47) owing to the moderate to high terpenes, CBD, $\alpha$-tocopherol and polyphenol contents in the diet, which are transferable to tissues. Thus, feeding hemp byproducts could have positive effects on meat oxidative stability, and merits research.

\section{FURTHER RESEARCH}

Increasing consumer demand for hemp products is driving a wave of regulatory changes allowing its commercial production globally. Consumers generally perceive hemp products such as fiber, seed, seed oil, CBD oil, and CBD fortified commodities as organic and healthy, hence, are willing to pay a premium for them (4). Hemp leaves, seed, hulls and HSC have potential as livestock

TABLE 7 | Growth performance of lambs and steers fed hempseed cake or other protein feed.

\begin{tabular}{lcccccc}
\hline & \multicolumn{2}{c}{ Lambs } & & & \multicolumn{2}{c}{ Steers } \\
\cline { 2 - 6 } Attributes & HSC & CM & SEM & HS & SBM \\
\hline Total gain (kg) & 6.4 & 9.5 & 0.52 & 192.6 & 193.3 \\
Average daily gain (kg/d) & 119 & 175 & 9.6 & 1.16 & 1.16 \\
Body condition score (1-5) & 2.9 & 3 & 0.04 & - & 0.95 \\
Feed conversion (DM/gain) & 7.9 & 5 & 0.37 & 0.133 & 0.133
\end{tabular}

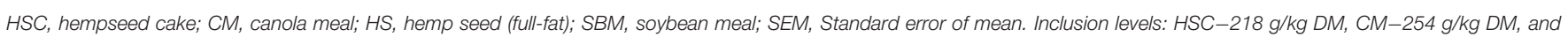
HS-140 g/kg DM.

Source: $(19,79)$. 
TABLE 8 | Fatty acid profile (Mean \pm SD) of longissimus dorsi from steers and lambs fed hempseed cake, canola, or soybean meal.

\begin{tabular}{|c|c|c|c|c|}
\hline \multirow[b]{2}{*}{ Fatty acids ( $\%$ Total FA) } & \multicolumn{2}{|c|}{ Steers } & \multicolumn{2}{|c|}{ Lambs } \\
\hline & HSC & SBM & HSC & CM \\
\hline Total fat content $(\mathrm{g} / 100 \mathrm{~g})$ & $10.6 \pm 4.18$ & $7.50 \pm 2.14$ & $3.70 \pm 0.67$ & $3.6 \pm 0.67$ \\
\hline Palmitic acid & $28.3 \pm 1.17$ & $31.0 \pm 2.65$ & $23.0 \pm 1.48$ & $22.1 \pm 1.48$ \\
\hline Stearic acid & $13.1 \pm 0.71$ & $12.8 \pm 0.83$ & $14.7 \pm 1.24$ & $13.8 \pm 1.24$ \\
\hline Oleic acid & $44.9 \pm 1.16$ & $41.8 \pm 2.78$ & $37.4 \pm 2.06$ & $41.2 \pm 2.06$ \\
\hline Linoleic acid & $1.20 \pm 0.10$ & $1.36 \pm 0.48$ & $4.49 \pm 0.55$ & $5.84 \pm 0.55$ \\
\hline$\gamma$-linolenic & - & - & $0.04 \pm 0.01$ & $0.06 \pm 0.01$ \\
\hline$\alpha$-linolenic & $0.25 \pm 0.03$ & $0.21 \pm 0.05$ & $0.61 \pm 0.09$ & $0.78 \pm 0.09$ \\
\hline Total saturated fatty acids & $44.6 \pm 1.09$ & $47.4 \pm 3.46$ & $41.3 \pm 2.80$ & $42.4 \pm 2.80$ \\
\hline Total monounsaturated fatty acids & $51.4 \pm 1.26$ & $48.4 \pm 2.75$ & $48.2 \pm 2.29$ & $44.9 \pm 2.29$ \\
\hline Total $n-6$ fatty acids & $1.52 \pm 0.49$ & $1.80 \pm 0.70$ & $5.79 \pm 0.72$ & $7.48 \pm 0.72$ \\
\hline Total $n-3$ fatty acids & $0.37 \pm 0.11$ & $0.36 \pm 0.15$ & $1.26 \pm 0.15$ & $1.54 \pm 0.15$ \\
\hline Total polyunsaturated fatty acids & $2.08 \pm 0.56$ & $2.28 \pm 0.85$ & $8.33 \pm 0.85$ & $10.59 \pm 0.85$ \\
\hline
\end{tabular}

HSC, hempseed cake; SBM, soybean meal; CM, canola meal.

Source: $(95,127)$.

feed and meat preservatives. In vitro studies suggest antimicrobial and antioxidant properties of hemp bioactive compounds, which are yet to be affirmed in vivo. Some studies have already included hemp by-products as protein sources in finishing diets for goats, sheep, cattle, and monogastrics $(3,6,95,127)$. Either neutral or superior animal health and performance attributes for hemp byproduct fed animals compared to conventional oilseed cakes were reported (6). However, there is still a gap in understanding the impact of hemp by-products on nutrient digestibility, nitrogen, and methane emissions, nutritional disorders, gut health, and meat quality, thus more research is warranted.

Overall, nutrient and bioactive compounds in hemp byproducts are biologically accessible in the GIT and available in the animal body system (109), but details on their bioavailability are incomplete. These bioactive compounds have been identified in the circulatory system, muscle, and brain tissue, feces and urine in animal models (84). Retention of these bioactive compounds in milk has been investigated (89), but for meat, it is yet to be determined. If these bioactive compounds are retained in meat, it would be important to determine their efficacy in enhancing keeping and eating qualities of meat. Bioavailability of bioactive compounds of hemp by-products could be determined using in vitro digestion, in-vivo and/or ex-vivo using blood and organs, respectively $(80,99)$. Various techniques have been developed

\section{REFERENCES}

1. Salami SA, Luciano G, O'Grady MN, Biondi L, Newbold CJ, Kerry JP, et al. Sustainability of feeding plant by-products: a review of the implications for ruminant meat production. Anim Feed Sci Technol. (2019) 251:3755. doi: 10.1016/j.anifeedsci.2019.02.006

2. EFSA-FEEDAP. Scientific opinion on the safety of hemp (Cannabis genus) for use as animal feed. EFSA J. (2011) 9:1-41. doi: 10.2903/j.efsa.2011.2011 to assess ruminal degradability and intestinal digestibility of feed ingredients in-vitro $(131,132)$. Distribution of hemp byproducts' bioactive compounds among major tissues can also be determined ex-vivo using the GC-MS procedure (133). The overall challenge in ruminant production is estimating the transfer of bioactive compounds from hemp by-products into meat and establishing their bioefficacy in improving animal health and production as well as keeping and eating qualities of meat.

\section{AUTHOR CONTRIBUTIONS}

FS: drafted the manuscript with editorial inputs from CK, OC, MM, and CM. CM: conceptualized the review and acquired funding. All authors contributed to the article and approved the submitted version.

\section{FUNDING}

The authors acknowledge South African Research Chairs Initiative in Meat Science: Genomics to Nutriomics (UID-84633) funded by the National Research Foundation (NRF) and Department of Science and Technology of South Africa for the $\mathrm{PhD}$ award and availing funds for the research.

3. Mierlit $\breve{a}$ D. Fatty acids profile and oxidative stability of eggs from laying hens fed diets containing hemp seed or hempseed cake. S Afr J Anim Sci. (2019) 49:311-21. doi: 10.4314/sajas.v4 9i2.11

4. Schultz CJ, Lim WL, Khor SF, Neumann KA, Schulz JM, Ansari O, et al. Consumer and health-related traits of seed from selected commercial and breeding lines of industrial hemp, Cannabis sativa L. J Agric Food Res. (2020) 2:100025. doi: 10.1016/j.jafr.2020.100025 
5. Leonard W, Zhang P, Ying D, Fang Z. Hempseed in food industry: nutritional value, health benefits, and industrial applications. Compr Rev Food Sci Food Saf. (2020) 19:282-308. doi: 10.1111/1541-4337.12517

6. Hessle A, Eriksson M, Nadeau E, Turner T, Johansson B. Cold-pressed hempseed cake as a protein feed for growing cattle. Acta Agric Scand A Anim Sci. (2008) 58:136-45. doi: 10.1080/09064700802452192

7. Mustafa AF, McKinnon JJ, Christensen DA. The nutritive value of hemp meal for ruminants. Can J Anim Sci. (1999) 79:91-5. doi: 10.4141/A98-031

8. Canadian Food Inspection Agency. Specific Registration Information by Feed Type. Regulatory Guidance. Government of Canada. (2020). Available online at: https://www.inspection.gc.ca/animal-health/livestock-feeds/ regulatory-guidance/rg-1/chapter-3/eng/1329319549692/1329439126197? chap $=0$ (accessed September 14, 2020).

9. US FDA. FDA Regulation of Cannabis and Cannabis-Derived Products, Including Cannabidiol (CBD). US Food \& Drug Administration. (2020). p. 18. Available online at: https://www.fda.gov/news-events/public-healthfocus/fda-regulation-cannabis-and-cannabis-derived-products-includingcannabidiol-cbd\#dietarysupplements\%0A (accessed September 14, 2020).

10. Ujváry I, Hanuš L. Human metabolites of cannabidiol: a review on their formation, biological activity, and relevance in therapy. Cannabis Cannabinoid Res. (2016) 1:90-101. doi: 10.1089/can.2015.0012

11. Hazekamp A, Fischedick JT, Llano MD, Lubbe A, Ruhaak RL. Chemistry of cannabis. In: Liu HW (Ben), Mander L, editors. Comprehensive Natural Products II: Chemistry and Biology. London: Elsevier (2010). p. 1033-84.

12. García-Tejero IF, Durán-Zuazo VH, Pérez-Álvarez R, Hernández A, Casano S, Morón M, et al. Impact of plant density and irrigation on yield of hemp (Cannabis sativa L.) in a mediterranean semi-arid environment. J Agric Sci Technol. (2014) 16:887-95.

13. FAOSTAT. Global Hempseed Production. Rome. (2020). Available online at: http://www.fao.org/faostat/en/\#data/QC (accessed September 14, 2020).

14. Callaway JC. Hempseed as a nutritional resource: an overview. Euphytica. (2004) 140:65-72. doi: 10.1007/s10681-004-4811-6

15. House JD, Neufeld J, Leson G. Evaluating the quality of protein from hemp seed (Cannabis sativa L.) products through the use of the protein digestibility-corrected amino acid score method. J Agric Food Chem. (2010) 58:11801-7. doi: 10.1021/jf102636b

16. Halle I, Schöne F. Influence of rapeseed cake, linseed cake and hemp seed cake on laying performance of hens and fatty acid composition of egg yolk. J fur Verbraucherschutz und Leb. (2013) 8:185-93. doi: 10.1007/s00003-013-0822-3

17. Karlsson L, Finell M, Martinsson K. Effects of increasing amounts of hempseed cake in the diet of dairy cows on the production and composition of milk. Animal. (2010) 4:1854-60. doi: 10.1017/S1751731110001254

18. Pojić M, Mišan A, Sakač M, Hadnadev DT, Šarić B, Milovanović I, et al. Characterization of byproducts originating from hemp oil processing. J Agric Food Chem. (2014) 62:12346-442. doi: 10.1021/jf5044426

19. Gibb DJ, Shah MA, Mir PS, McAllister TA. Effect of full-fat hemp seed on performance and tissue fatty acids of feedlot cattle. Can J Anim Sci. (2005) 85:223-30. doi: 10.4141/A04-078

20. Paula EM, Broderick GA, Danes MAC, Lobos NE, Zanton GI, Faciola AP. Effects of replacing soybean meal with canola meal or treated canola meal on ruminal digestion, omasal nutrient flow, and performance in lactating dairy cows. J Dairy Sci. (2018) 101:328-39. doi: 10.3168/jds.2017-13392

21. Banaszkiewicz T. Nutritional value of soybean meal. In: Hany E-S, editor. Soybean and Nutrition. Rijeka: InTechOpen (2016) p. 1-20.

22. Audu BS, Ofojekwu PC, Ujah A, Ajima MNO. Phytochemical, proximate composition, amino acid profile and characterisation of Marijuana (Canabia sativa). Phytopharmacology. (2014) 3:35-43.

23. Lepescu M. Industrial Hemp Production Trade and Regulation. Ottawa. (2019) Available online at: https://apps.fas.usda.gov/ newgainapi/api/report/downloadreportbyfilename?filename $=$ IndustrialHempProductionTradeand Regulation_Ottawa_Canada_826-2019.pdf (accessed September 14, 2020).

24. Lee V. Projections: US Leads in Global Hemp Cultivation. Cannabis Business Times. (2019) Available online at: http://magazine.cannabisbusinesstimes. com/article/october-2019/projections-us-leads-in-global-hempcultivation.aspx (accessed September 14, 2020).
25. Ali EMM, Almagboul AZI, Khogali SME, Gergeir UMA. Antimicrobial activity of Cannabis sativa L. J Chinese Med. (2012) 3:61-4. doi: $10.4236 / \mathrm{cm} .2012 .31010$

26. Głodowska M, Łyszcz M. Cannabis sativa L. and its antimicrobial properties - a review. Strona. (2017) 77-82.

27. Andre CM, Hausman JF, Guerriero G. Cannabis sativa: the plant of the thousand and one molecules. Front Plant Sci. (2016) 7:19. doi: 10.3389/fpls.2016.00019

28. Hartsel JA, Eades J, Hickory B, Alexandros M. Cannabis sativa and hemp. In: Gupta RC, editor. Nutraceuticals: Efficacy, Safety and toxicity. London, UK: Academic Press (2016) p. 735-54.

29. Department of health. Regulation gazette No. 40949. Government Gazette Pretoria, South Africa: Department of health (2019). p. 1-132.

30. Faugno S, Piccolella S, Sannino M, Principio L, Crescente G, Baldi GM, et al. Can agronomic practices and cold-pressing extraction parameters affect phenols and polyphenols content in hempseed oils? Ind Crops Prod. (2019) 130:511-9. doi: 10.1016/j.indcrop.2018.12.084

31. Mihoc M, Pop G, Alexa E, Radulov I. Nutritive quality of romanian hemp varieties (Cannabis sativa L.) with special focus on oil and metal contents of seeds. Chem Cent J. (2012) 6:122. doi: 10.1186/1752-153X-6-122

32. NRC. Nutrient Requirements of Goats: Angora, Dairy, and Meat Goats in Temperate and Tropical Countries. Washington, DC: The National Academies Press (2007).

33. CSIRO. Nutrient requirements of domesticated ruminants. In: Freer M, Dove H, Nolan JV, editors. Nutrient Requirements of Domesticated Ruminants. Collingwood: CSIRO Pub (2007).

34. Mihoc M, Pop G, Alexa E, Dem D, Militaru A. Microelements distribution in whole hempseeds (Cannabis sativa L.) and in their fractions. Rev Chim. (2013) 64:776-80.

35. Siano F, Moccia S, Picariello G, Russo GL, Sorrentino G, Di Stasio M, et al. Comparative study of chemical, biochemical characteristic and ATR-FTIR analysis of seeds, oil and flour of the edible fedora cultivar hemp (Cannabis sativa L.). Molecules. (2019) 24:83. doi: 10.3390/molecules 24010083

36. NRC. Nutrient Requirements of Beef Cattle. 8th ed. Washington DC, USA: National Academies Press (2000).

37. Ferreira A V. Essential amino acid requirements of meat and milk goats. South Afr J Anim Sci. (2004) 34:46-8.

38. Çakaloglu B, Özyurt VH, Ötleş S. Cold press in oil extraction. A review. Ukr Food J. (2018) 7:640-54. doi: 10.24263/2304-974X-2018-7-4-9

39. Pantoja J, Firkins JL, Eastridge ML, Hull BL. Effects of fat saturation and source of fiber on site of nutrient digestion and milk production by lactating dairy cows. J Dairy Sci. (1994) 77:2341-56. doi: 10.3168/jds.S0022-0302(94)77177-0

40. Harper K, McNeill D. The role iNDF in the regulation of feed intake and the importance of its assessment in subtropical ruminant systems (the role of iNDF in the regulation of forage intake). Agriculture. (2015) 5:77890. doi: 10.3390/agriculture5030778

41. Avondo M, Biondi L, Pagano R, Bonanno A, Lutri L. Feed intake. In: Cannas A, and Pulina G, editors. Dairy Goats, Feeding and Nutrition. Cambridge: CABI International (2008) p. 147-60. doi: 10.1079/9781845933487.0147

42. Vonapartis E, Aubin MP, Seguin P, Mustafa AF, Charron JB. Seed composition of ten industrial hemp cultivars approved for production in Canada. J Food Compos Anal. (2015) 39:8-12. doi: 10.1016/j.jfca.2014.11.004

43. Brenneisen R. Chemistry and analysis of phytocannabinoids and other cannabis constituents. In: ElSohly MA, editor. Marijuana and the Cannabinoids. Totowa, NJ: Humana Press (2007) p. 17-49. doi: 10.1007/978-1-59259-947-9_2

44. Palade LM, Habeanu M, Marin DE, Chedea VS, Pistol GC, Grosu IA, et al. Effect of dietary hemp seed on oxidative status in sows during late gestation and lactation and their offspring. Animals. (2019) 9:194. doi: 10.3390/ani9040194

45. Izzo L, Castaldo L, Narváez A, Graziani G, Gaspari A, RodríguezCarrasco Y, et al. Analysis of phenolic compounds in commercial cannabis sativa L. inflorescences using UHPLC-Q-Orbitrap HRMs. Molecules. (2020) 25:631. doi: 10.3390/molecules25030631

46. Irakli M, Tsaliki E, Kalivas A, Kleisiaris F, Sarrou E, Cook CM. Effect of genotype and growing year on the nutritional, phytochemical, and 
antioxidant properties of industrial hemp (Cannabis sativa L.) seeds. Antioxidants. (2019) 8:20-5. doi: 10.3390/antiox8100491

47. Mierliţă D. Effects of diets containing hemp seeds or hemp cake on fatty acid composition and oxidative stability of sheep milk. S Afr J Anim Sci. (2018) 48:504. doi: 10.4314/sajas.v4 $8 \mathrm{i} 3.11$

48. Kriese U, Schumann E, Weber WE, Beyer M, Brühl L, Matthäus B. Oil content, tocopherol composition and fatty acid patterns of the seeds of 51 Cannabis sativa L. genotypes. Euphytica. (2004) 137:33951. doi: 10.1023/B:EUPH.0000040473.23941.76

49. Matthäus B, Schumann E, Brühl L, Kriese U. Hempseed oil-influence of the genotype on the composition in a two-year study. J Ind Hemp. (2006) 10:45-65. doi: 10.1300/J237v10n02_05

50. Frassinetti S, Moccia E, Caltavuturo L, Gabriele M, Longo V, Bellani L, et al. Nutraceutical potential of hemp (Cannabis sativa L.) seeds and sprouts. Food Chem. (2018) 262:56-66. doi: 10.1016/j.foodchem.2018.04.078

51. Smeriglio A, Galati EM, Monforte MT, Lanuzza F, D’Angelo V, Circosta C. Polyphenolic compounds and antioxidant activity of cold-pressed seed oil from finola cultivar of Cannabis sativa L. Phyther Res. (2016) 1307:1298307. doi: $10.1002 /$ ptr.5623

52. Yu LL, Zhou KK, Parry J. Antioxidant properties of cold-pressed black caraway, carrot, cranberry, and hemp seed oils. Food Chem. (2005) 91:7239. doi: 10.1016/j.foodchem.2004.06.044

53. Mattila PH, Pihlava JM, Hellström J, Nurmi M, Eurola M, Mäkinen $\mathrm{S}$, et al. Contents of phytochemicals and antinutritional factors in commercial protein-rich plant products. Food Qual Saf. (2018) 2:2139. doi: 10.1093/fqsafe/fyy021

54. Russo R, Reggiani R. Variability in antinutritional compounds in hempseed meal of italian and french varieties. Plant. (2013) 1:25. doi: 10.11648/j.plant.20130102.13

55. Turner CE, Elsohly MA, Boeren EG. Constituents of Cannabis Sativa L. xvii. a review of the natural constituents. J Nat Prod. (1980) 43:169234. doi: $10.1021 / \mathrm{np} 50008 \mathrm{a} 001$

56. Yan X, Zhou Y, Tang J, Ji M, Lou H, Fan P. Diketopiperazine indole alkaloids from hemp seed. Phytochem Lett. (2016) 18:77-82. doi: 10.1016/j.phytol.2016.09.001

57. Smeds AI, Eklund PC, Willför SM. Content, composition, and stereochemical characterisation of lignans in berries and seeds. Food Chem. (2012) 134:1991-8. doi: 10.1016/j.foodchem.2012.03.133

58. Yan X, Tang J, Dos Santos Passos C, Nurisso A, Simoes-Pires CA, Ji M, et al. Characterization of lignanamides from hemp (Cannabis Sativa L.) seed and their antioxidant and acetylcholinesterase inhibitory activities. J Agric Food Chem. (2015) 63:10611-9. doi: 10.1021/acs.jafc.5b05282

59. de Silva SF, Alcorn J. Flaxseed lignans as important dietary polyphenols for cancer prevention and treatment: chemistry, pharmacokinetics, and molecular targets. Pharmaceuticals. (2019) 12:21-38. doi: 10.3390/ph12020068

60. Im S, Nam TG, Lee SG, Kim YJ, Chun OK, Kim DO. Additive antioxidant capacity of vitamin C and tocopherols in combination. Food Sci Biotechnol. (2014) 23:693-9. doi: 10.1007/s10068-014-0094-4

61. Leizer C, Ribnicky D, Poulev A, Dushenkov S, Raskin I. The composition of hemp seed oil and its potential as an important source of nutrition. J Nutraceuticals Funct Med Foods. (2000) 2:35-53. doi: 10.1300/J133v02n04_04

62. Bellés $M$, del Mar Campo M, Roncalés P, Beltrán JA. Supranutritional doses of vitamin E to improve lamb meat quality. Meat Sci. (2019) 149:1423. doi: 10.1016/j.meatsci.2018.11.002

63. Álvarez I, De La Fuente J, Díaz MT, Lauzurica S, Pérez C, Cañeque V. Estimation of $\alpha$-tocopherol concentration necessary to optimise lamb meat quality stability during storage in high-oxygen modified atmosphere using broken-line regression analysis. Animal. (2008) 2:140511. doi: $10.1017 / S 1751731108002590$

64. Liu K, Ge S, Luo H, Yue D, Yan L. Effects of dietary vitamin E on muscle vitamin $\mathrm{E}$ and fatty acid content in Aohan fine-wool sheep. J Anim Sci Biotechnol. (2013) 4:21. doi: 10.1186/2049-1891-4-21

65. Tripathi MK, Mishra AS. Prospects and problems of dietary glucosinolates in animal feeding. $A d v$ Dairy Res. (2017) 5:5-8. doi: 10.4172/2329-888X.1000180
66. Taylor N, Bowman JGP, Anderson KA, Surber LMM, Blake TK, Raboy V, et al. Phytic acid levels in barley for beef cattle. In Western Section, American Society of Animal Science. Illinois, IL: American Society of Animal Science (2001) p. 426-9.

67. Di Mambro VM, Azzolini AECS, Valim YML, Fonseca MJV. Comparison of antioxidant activities of tocopherols alone and in pharmaceutical formulations. Int $J$ Pharm. (2003) 262:93-9. doi: 10.1016/S0378-5173(03)00333-8

68. Liu D, Shi J, Colina Ibarra A, Kakuda Y, Jun Xue S. The scavenging capacity and synergistic effects of lycopene, vitamin $\mathrm{E}$, vitamin $\mathrm{C}$, and $\beta$-carotene mixtures on the DPPH free radical. LWT Food Sci Technol. (2008) 41:13449. doi: 10.1016/j.lwt.2007.08.001

69. Naguib YMA, Hari SP, Richard Passwater J, Huang D. Antioxidant activities of natural vitamin E formulations. J Nutr Sci Vitaminol. (2003) 49:21720. doi: $10.3177 /$ jnsv.49.217

70. Zhong Y, Shahidi F. Methods for the assessment of antioxidant activity in foods. In: Fereidoon S, editor. Handbook of Antioxidants for Food Preservation. Amsterdam: Woodhead Publishing (2015) p. 287-333. doi: 10.1016/B978-1-78242-089-7.00012-9

71. Chen T, He J, Zhang J, Li X, Zhang H, Hao J, et al. The isolation and identification of two compounds with predominant radical scavenging activity in hempseed (seed of Cannabis sativa L.). Food Chem. (2012) 134:1030-7. doi: 10.1016/j.foodchem.2012.03.009

72. Novak J, Zitterl-Eglseer K, Deans SG, Franz CM. Essential oils of different cultivars of Cannabis sativa L. and their antimicrobial activity. Flavour Fragr J. (2001) 16:259-62. doi: 10.1002/ffj.993

73. Frassinetti S, Gabriele M, Moccia E, Longo V, Di Gioia D. Antimicrobial and antibiofilm activity of Cannabis sativa L. seeds extract against Staphylococcus aureus and growth effects on probiotic Lactobacillus spp. LWT Food Sci Technol. (2020) 124:109149. doi: 10.1016/j.lwt.2020.109149

74. Nissen L, Zatta A, Stefanini I, Grandi S, Sgorbati B, Biavati B, et al. Characterization and antimicrobial activity of essential oils of industrial hemp varieties (Cannabis sativa L.). Fitoterapia. (2010) 81:4139. doi: 10.1016/j.fitote.2009.11.010

75. Li ZH, Cai M, Liu YS, Sun PL, Luo SL. Antibacterial activity and mechanisms of essential oil from Citrus medica L. Var. Sarcodactylis. Molecules. (2019) 24:1577. doi: 10.3390/molecules24081577

76. Trombetta D, Castelli F, Sarpietro MG, Venuti V, Cristani $\mathrm{M}$, Daniele C, et al. Mechanisms of antibacterial action of three monoterpenes. Antimicrob Agents Chemother. (2005) 49:2474-8. doi: 10.1128/AAC.49.6.2474-2478.2005

77. Bouarab-Chibane L, Forquet V, Lantéri P, Clément Y, Léonard-Akkari L, Oulahal N, et al. Antibacterial properties of polyphenols: characterization and QSAR (Quantitative structure-activity relationship) models. Front Microbiol. (2019) 10:829. doi: 10.3389/fmicb.2019.00829

78. Othman L, Sleiman A, Abdel-Massih RM. Antimicrobial activity of polyphenols and alkaloids in middle eastern plants. Front Microbiol. (2019) 10:911. doi: $10.3389 /$ fmicb.2019.00911

79. Karlsson L, Martinsson K. Growth performance of lambs fed different protein supplements in barley-based diets. Livest Sci. (2011) 138:12531. doi: 10.1016/j.livsci.2010.12.010

80. Santos DI, Saraiva JMA, Vicente AA, Moldão-Martins M. Methods for determining bioavailability and bioaccessibility of bioactive compounds and nutrients. In: Barba FJ, Saraiva JMA, Cravotto G, Lorenzo JM, editors. Innovative Thermal and Non-Thermal Processing, Bioaccessibility and Bioavailability of Nutrients and Bioactive Compounds. London: Elsevier Inc. (2019) p. 23-54. doi: 10.1016/B978-0-12-814174-8. 00002-0

81. Holst B, Williamson G. Nutrients and phytochemicals: from bioavailability to bioefficacy beyond antioxidants. Curr Opin Biotechnol. (2008) 19:7382. doi: 10.1016/j.copbio.2008.03.003

82. Kussmann M, Affolter M, Nagy K, Holst B, Fay LB. Mass spectrometry in nutrition: understanding dietary health effects at the molecular level. Mass Spectrom Rev. (2007) 26:727-50. doi: 10.1002/mas.20147

83. Rogosic J, Estell RE, Ivankovic S, Kezic J, Razov J. Potential mechanisms to increase shrub intake and performance of small ruminants in mediterranean shrubby ecosystems. Small Rumin Res. (2008) 74:115. doi: 10.1016/j.smallrumres.2007.07.006 
84. Brunet B, Doucet C, Venisse N, Hauet T, Hébrard W, Papet Y, et al. Validation of large white pig as an animal model for the study of cannabinoids metabolism: application to the study of THC distribution in tissues. Forensic Sci Int. (2006) 161:169-74. doi: 10.1016/j.forsciint.2006.04.018

85. Serrano E, Cornu A, Kondjoyan N, Agabriel J, Micol D. Traceability of grass feeding in beef: terpenes, 2,3-octanedione and skatole accumulation in adipose tissue of young bulls. Animal. (2011) 5:641-9. doi: 10.1017/S1751731110002296

86. Resconi VC, Escudero A, Campo MM. The development of aromas in ruminant meat. Molecules. (2013) 18:674881. doi: 10.3390/molecules18066748

87. Sivadier G, Ratel J, Engel E. Persistence of pasture feeding volatile biomarkers in lamb fats. Food Chem. (2010) 118:41825. doi: 10.1016/j.foodchem.2009.02.088

88. Sivadier G, Ratel J, Bouvier F, Engel E. Authentication of meat products: determination of animal feeding by parallel gc-ms analysis of three adipose tissues. J Agric Food Chem. (2008) 56:9803-12. doi: 10.1021/jf801276b

89. Jakubovic A, Tait RM, Mcgeer PL. Excretion of THC and its metabolites in Ewes' milk. Toxicol Appl Pharmacol. (1974) 28:38-43. doi: 10.1016/0041-008X(74)90128-8

90. Kuhnle GGC, Dell'Aquila C, Aspinall SM, Runswick SA, Mulligan AA, Bingham SA. Phytoestrogen content of foods of animal origin: dairy products, eggs, meat, fish, and seafood. J Agric Food Chem. (2008) 56:10099104. doi: $10.1021 / \mathrm{jf} 801344 \mathrm{x}$

91. Brito AF, Zang Y. A review of lignan metabolism, milk enterolactone concentration, and antioxidant status of dairy cows fed flaxseed. Molecules. (2019) 24:1-21. doi: 10.3390/molecules24010041

92. Moñino I, Martínez C, Sotomayor JA, Lafuente A, Jordán MJ. Polyphenols transmission to Segureño lamb meat from ewes' diet supplemented with the distillate from rosemary (Rosmarinus officinalis) leaves. J Agric Food Chem. (2008) 56:3363-7. doi: 10.1021/jf7036856

93. Keles G, Kocaman V, Ustundag AO, Zungur A, Ozdogan M. Growth rate, carcass characteristics and meat quality of growing lambs fed buckwheat or maize silage. Asian-Australasian J Anim Sci. (2018) 31:5228. doi: 10.5713/ajas.17.0296

94. O’Grady MN, Maher M, Troy DJ, Moloney AP, Kerry JP. An assessment of dietary supplementation with tea catechins and rosemary extract on the quality of fresh beef. Meat Sci. (2006) 73:132-43. doi: 10.1016/j.meatsci.2005.11.008

95. Turner T, Hessle A, Lundström K, Pickova J. Influence of hempseed cake and soybean meal on lipid fractions in bovine M. longissimus dorsi. Acta Agric Scand A Anim Sci. (2008) 58:152-60. doi: 10.1080/09064700802492354

96. Leedle RA, Leedle JA, Butine MD. Vitamin E is not degraded by ruminal microorganisms: assessment with ruminal contents from a steer fed a high-concentrate diet. J Anim Sci. (1993) 71:3442-50. doi: 10.2527/1993.71123442x

97. Bellés M, Alonso V, Roncalés P, Beltrán JA. Display stability of fresh and thawed lamb supplemented with vitamin $\mathrm{E}$ or sprayed with an antioxidant borage seed extract. J Sci Food Agric. (2018) 98:2871-9. doi: 10.1002/jsfa.8780

98. Liu Q, Scheller KK, Schaefer DM. Technical note: a simplified procedure for vitamin e determination in beef muscle. J Anim Sci. (1996) 74:240610. doi: 10.2527/1996.74102406x

99. Carbonell-Capella JM, Buniowska M, Barba FJ, Esteve MJ, Frígola A. Analytical methods for determining bioavailability and bioaccessibility of bioactive compounds from fruits and vegetables: a review. Compr Rev Food Sci Food Saf. (2014) 13:155-71. doi: 10.1111/1541-4337.12049

100. Bamikole MA, Ikhatua UJ. Compilation and adoption of ethno-veterinary medicine, traditional and other management practices by small ruminant farmers in Edo State Nigeria. Trop Anim Health Prod. (2009) 41:154961. doi: 10.1007/s11250-009-9346-3

101. Embaby MG, Günal M, Abughazaleh A. Effect of unconventional oils on in vitro rumen methane production and fermentation. Cienc e Investig Agrar. (2019) 46:276-85. doi: 10.7764/rcia.v46i3.2062

102. Maxin G, Ouellet DR, Lapierre H. Ruminal degradability of dry matter, crude protein, and amino acids in soybean meal, canola meal, corn, and wheat dried distillers grains. J Dairy Sci. (2013) 96:515160. doi: $10.3168 /$ jds.2012-6392
103. González J, Andrés S, Rodríguez CA, Alvir MR. In situ evaluation of the protein value of soybean meal and processed full fat soybeans for ruminants. J Anim Res. (2002) 51:455-64. doi: 10.1051/animres:2002039

104. Kamalak A, Canbolat O, Gurbuz Y, Ozay O. In situ ruminal dry matter and crude protein degradability of plant- and animal-derived protein sources in Southern Turkey. Small Rumin Res. (2005) 58:13541. doi: 10.1016/j.smallrumres.2004.09.006

105. Shen JS, Song LJ, Sun HZ, Wang B, Chai Z, Chacher B, et al. Effects of corn and soybean meal types on rumen fermentation, nitrogen metabolism and productivity in dairy cows. Asian-Australas J Anim Sci. (2015) 28:3519. doi: 10.5713/ajas.14.0504

106. Adeyemi KD, Sazili AQ, Ebrahimi M, Samsudin AA, Alimon AR, Karim $\mathrm{R}$, et al. Effects of blend of canola oil and palm oil on nutrient intake and digestibility, growth performance, rumen fermentation and fatty acids in goats. Anim Sci J. (2016) 87:1137-47. doi: 10.1111/asj.12549

107. Fiorentini G, Messana JD, Dian PHM, Reis RA, Canesin RC, Pires A V., et al. Digestibility, fermentation and rumen microbiota of crossbred heifers fed diets with different soybean oil availabilities in the rumen. Anim Feed Sci Technol. (2013) 181:26-34. doi: 10.1016/j.anifeedsci.2013.01.011

108. Mao HL, Wang JK, Zhou YY, Liu JX. Effects of addition of tea saponins and soybean oil on methane production, fermentation and microbial population in the rumen of growing lambs. Livest Sci. (2010) 129:5662. doi: 10.1016/j.livsci.2009.12.011

109. Karlsson L, Ruiz-Moreno M, Stern MD, Martinsson K. Effects of temperature during moist heat treatment on ruminal degradability and intestinal digestibility of protein and amino acids in hempseed cake. Asian-Australas J Anim Sci. (2012) 25:1559-67. doi: 10.5713/ajas.2012.12213

110. Krizsan SJ, Huhtanen P. Effect of diet composition and incubation time on feed indigestible neutral detergent fiber concentration in dairy cows. J Dairy Sci. (2013) 96:1715-26. doi: 10.3168/jds.2012-5752

111. Stern MD, Varga GA, Clark JH, Firkins JL, Huber JT, Palmquist DL. Evaluation of chemical and physical properties of feeds that affect protein metabolism in the rumen. J Dairy Sci. (1994) 77:276286. doi: 10.3168/jds.S0022-0302(94)77219-2

112. France J, Dijkstra J. Volatile fatty acid production. In: Dijkstra J, Forbes JM, France J, editors. Quantitative Aspects of Ruminant Digestion and Metabolism. 2nd ed. Oxfordshire: CABI International (2005) p. 15776. doi: 10.1079/9780851998145.0000

113. Lillis L, Boots B, Kenny DA, Petrie K, Boland TM, Clipson N, et al. The effect of dietary concentrate and soya oil inclusion on microbial diversity in the rumen of cattle. J Appl Microbiol. (2011) 111:142635. doi: 10.1111/j.1365-2672.2011.05154.x

114. Ivan M, Petit HV, Chiquette J, Wright ADG. Rumen fermentation and microbial population in lactating dairy cows receiving diets containing oilseeds rich in C-18 fatty acids. Br J Nutr. (2013) 109:1211-8. doi: 10.1017/S0007114512003030

115. Wang S, Kreuzer M, Braun U, Schwarm A. Effect of unconventional oilseeds (safflower, poppy, hemp, camelina) on in vitro ruminal methane production and fermentation. J Sci Food Agric. (2017) 97:3864-70. doi: 10.1002/jsfa.8260

116. Patra A, Park T, Kim M, Yu Z. Rumen methanogens and mitigation of methane emission by anti-methanogenic compounds and substances. J Anim Sci Biotechnol. (2017) 8:13. doi: 10.1186/s40104-017-0145-9

117. Patra AK. The effect of dietary fats on methane emissions, and its other effects on digestibility, rumen fermentation and lactation performance in cattle: a meta-analysis. Livest Sci. (2013) 155:244-54. doi: 10.1016/j.livsci.2013. 05.023

118. Kortekaas S, Soto M, Vicent T, Field JA, Lettinga G. Contribution of extractives to methanogenic toxicity of hemp black liquor. J Ferment Bioeng. (1995) 80:383-8. doi: 10.1016/0922-338X(95)94208-9

119. Patra AK, Saxena J. Dietary phytochemicals as rumen modifiers: a review of the effects on microbial populations. Antonie Van Leeuwenhoek. (2009) 96:363-75. doi: 10.1007/s10482-009-9364-1

120. Beauchemin KA, McAllister TA, McGinn SM. Dietary mitigation of enteric methane from cattle. CAB Rev Perspect Agric Vet Sci Nutr Nat Resour. (2009) 4:1-18. doi: 10.1079/PAVSNNR20094035

121. Oh HK, Sakai T, Jones MB, Longhurst WM. Effect of various essential oils isolated from douglas fir needles upon sheep 
and deer rumen microbial activity. Appl Microbiol. (1967) 15:777-84. doi: 10.1128/AEM.15.4.777-784.1967

122. Kumar R, Singh M. Tannins: their adverse role in ruminant nutrition. J Agric Food Chem. (1984) 32:447-53. doi: 10.1021/jf00123a006

123. Min BR, Barry TN, Attwood GT, McNabb WC. The effect of condensed tannins on the nutrition and health of ruminants fed fresh temperate forages: a review. Anim Feed Sci Technol. (2003) 106:3-19. doi: 10.1016/S0377-8401(03)00041-5

124. McMahon LR, McAllister TA, Berg BP, Majak W, Acharya SN, Popp JD, et al. A review of the effects of forage condensed tannins on ruminal fermentation and bloat in grazing cattle. Can J Plant Sci. (2000) 80:46985. doi: 10.4141/P99-050

125. Koenig KM, Beauchemin KA, McGinn SM. Feeding condensed tannins to mitigate ammonia emissions from beef feedlot cattle fed high-protein finishing diets containing distillers grains. J Anim Sci. (2018) 96:441430. doi: 10.1093/jas/sky274

126. Naumann HD, Tedeschi LO, Zeller WE, Huntley NF. The role of condensed tannins in ruminant animal production: advances, limitations and future directions. Rev Bras Zootec. 46:929-49. doi: 10.1590/s1806-92902017001200009

127. Turner TD, Karlsson L, Mapiye C, Rolland DC, Martinsson K, Dugan MER. Dietary influence on the $\mathrm{m}$. longissimus dorsi fatty acid composition of lambs in relation to protein source. Meat Sci. (2012) 91:4727. doi: 10.1016/j.meatsci.2012.02.034

128. Chen L, Li Z, Everaert N, Lametsch R, Zhang D. Quantitative phosphoproteomic analysis of ovine muscle with different postmortem glycolytic rates. Food Chem. (2019) 280:2039. doi: 10.1016/j.foodchem.2018.12.056
129. Li Z, Li M, Du M, Shen QW, Zhang D. Dephosphorylation enhances postmortem degradation of myofibrillar proteins. Food Chem. (2018) 245:233-9. doi: 10.1016/j.foodchem.2017.09.108

130. Nassu RT, Dugan MER, Juárez M, Basarab JA, Baron VS, Aalhus JL. Effect of $\alpha$-tocopherol tissue levels on beef quality. Animal. (2011) 5:2010 8. doi: $10.1017 /$ S1751731111001182

131. Leeuw KJ, Palić D, Siebrits FK, Muller H, Hindle VA. Prediction of in vivo organic matter digestibility of ruminant feeds using in vitro techniques. $S$ Afr J Anim Sci. (2019) 48:907. doi: 10.4314/sajas.v48i5.10

132. Michalet-Doreau B, Ould-Bah MY. In vitro and in sacco methods for the estimation of dietary nitrogen degradability in the rumen: a review. Anim Feed Sci Technol. (1992) 40:57-86. doi: 10.1016/0377-8401(92) 90112-J

133. EFSA CONTAM Panel. Scientific opinion on the risks for human health related to the presence of tetrahydrocannabinol (THC) in milk and other food of animal origin. EFSA J. (2015) 13:4141. doi: 10.2903/j.efsa.2015.4141

Conflict of Interest: The authors declare that the research was conducted in the absence of any commercial or financial relationships that could be construed as a potential conflict of interest.

Copyright (c) 2020 Semwogerere, Katiyatiya, Chikwanha, Marufu and Mapiye. This is an open-access article distributed under the terms of the Creative Commons Attribution License (CC BY). The use, distribution or reproduction in other forums is permitted, provided the original author(s) and the copyright owner(s) are credited and that the original publication in this journal is cited, in accordance with accepted academic practice. No use, distribution or reproduction is permitted which does not comply with these terms. 